\title{
КОМПОНЕНТИ НАВЧАННЯ АНГЛЙСЬКОЇ ЛЕКСИКИ В АВІАЦІЙНОМУ ВНЗ
}

Файнман І. Б., Токарь Є. Б. Компоненти навчання англійської лексики в авіаційному ВНЗ.

У статті розглянуто питання навчання англійської лексики студентів авіаційних вищих навчальних закладів. Виокремлено низку теоретичних та концептуальних ідей, що лягли в основу розробки компонентної структури навчання лексики. Увагу зосереджено на визначенні компонентів навчання лексики майбутніх авіаційних фахівців 3 урахуванням наявності процесів опосередкованого та цілеспрямованого вивчення студентами нових слів. Проаналізовано чотири компоненти, а саме: систематизоване свідоме навчання спеціально відібраних лексичних одиниць; розширення мовного досвіду студентів; навчання студентів стратегій вивчення лексичних одиниць; розвиток

(ㄱ І. Б. Файнман, Є. Б. Токарь, 2018. -260- 
лексичної свідомості.

Ключові слова: іншомовна авіаційна лексика, навчання лексики, вивчення лексичних одиниць, компоненти навчання лексики.

Файнман И. Б., Токарь Е. Б. Компоненты обучения английской лексике в авиационном ВУЗе.

В статье рассматриваются вопросы обучения студентов авиационных вузов английской лексике. Выделяется ряд теоретических и концептуальных идей, которые легли в основу разработки компонентной структуры обучения лексике. Внимание акцентируется на определении компонентов обучения лексике будущих авиационных специалистов с учетом наличия процессов опосредованного и целенаправленного изучения студентами новых слов. Анализируются четыре компонента, а именно: систематизированное сознательное обучение специально отобранных лексических единиц; расширение языкового опыта студентов; обучение студентов стратегиям изучения лексических единиц; развитие лексического сознания.

Ключевые слова: иноязычная авиационная лексика, обучение лексике, изучение лексических единиц, компоненты обучения лексике.

Fainman I. B., Tokar Ye. B. Components of teaching English vocabulary in Aviation universities and colleges.

This paper explores English vocabulary teaching in aviation higher educational establishments, namely tries to define components of teaching vocabulary to aviation students. The starting point of the study is to provide theoretical background and define basic conceptual ideas. Herein, the authors underline the necessity of explicit vocabulary instruction and systematic regular planned work on expanding students' vocabulary. However, implicit learning while reading and listening is stated to be no less important. Thus, the authors come to the conclusion that both sides of the process should be combined into an effective method of teaching vocabulary. Within this viewpoint four components of teaching English vocabulary to aviation students are defined. Explicit teaching individual words is distinguished to be the first component. It involves teachers' direct vocabulary instruction as for specifically chosen lexical items. It turns to have best possible results when lexical units are connected with key concepts of the lesson or are the ones used in general language. Providing rich language experience is the second component which deals with students' vocabulary expansion while reading, listening and speaking. The teacher's role lies in working out activities aimed at effective vocabulary learning while reading as well as just reading aloud and discussions. The third component, teaching word-learning strategies, is aimed at teaching students to learn words themselves. It includes morphemic analysis, exploring the context and using dictionaries while learning new words. Fostering word consciousness, i.e. awareness of and interest in words, is a significant element in 
vocabulary teaching providing background for further words learning. It covers word games, tongue twisters, jokes, emphasizing interesting words, etc.

Key words: explicit teaching, incidental learning, component, vocabulary instruction, word-learning strategy, word consciousness.

Якісна підготовка авіаційного фахівця наразі неможлива без грунтовного підходу до викладання англійської мови. Оскільки значна частина виконуваних авіатором завдань на робочому місці пов'язана саме 3 використанням мови, то й у процесі професійної підготовки мовна освіта потребує достатньої уваги науковців та практиків. Відтак питання вдосконалення англомовної підготовки авіаторів, розширення їх мовних можливостей, зміна вектору розвитку іншомовних навичок від пасивного сприйняття до активної участі в освітньому процесі $\epsilon$ зараз надзвичайно нагальними в наукових дослідженнях.

Лексична компетенція авіатора займає важливе місце в його загальній комунікативній компетенції, а вокабуляр поруч iз вимовою та граматикою є основою для подальшого формування продуктивних навичок говоріння (fluency) та сприйняття на слух (comprehension), що, своєю чергою, об'єднуються задля забезпечення уміння мовленнєвої взаємодії (proficiency in interaction) [7, с. 2-9]. Навчання лексики та формування лексичної компетенції майбутнього авіаційного фахівця вимагають науково обгрунтованого й ретельно спланованого підходу, адже на виході мають гарантувати авіатору необхідний рівень навичок та умінь.

Проблеми навчання англомовної лексики в підготовці авіаційних фахівців попри їх значущість наразі не набули достатньо широкого висвітлення у світових наукових дослідженнях $з$ філології та методики викладання мов. На сьогодні описано потреби студентів авіаційного профілю щодо вивчення лексики (N. Koparan), визначено складнощі (challenges) навчання лексики в авіаційному BН3 (S. Y. E. Secer, M. Sahin), виокремлено низку методів навчання авіаційної лексики (A. Wang).

Н. Копаран (2017), провівши опитування й інтерв'ю (ㄱ.Б.Ф.Фйнман, Є. Б. Токарь, 2018. -262- 
студентів, описав їх потреби щодо покращення навчання лексики. С. Сечер та М. Сахін (2014) також вирізняють низку проблем i труднощів у навчанні лексики в курсі авіаційної англійської мови, але подають не загальний опис, а класифікують їх у три категорії. Дослідники виокремили: 1) проблеми, що виникають через мовну компетентність і мотивацію студентів; 2) проблеми, породжені нестачею досвіду викладання авіаційної англійської мови у викладачів; 3) проблеми, спричинені особливостями програми курсу авіаційної англійської. Проте дослідники не дають грунтовних методичних розробок для спланованої та систематичної роботи щодо подолання цих труднощів, а обмежуються лише загальними рекомендаціями й порадами стосовно відповідних проблем.

А. Ванг (2011) визнає системність авіаційної лексики та іiі розподіл за авіаційними секторами (авіаційна історія, структура літака, аеропорт, управління повітряним рухом тощо) і класами (технічна, напівтехнічна та загальна лексика). Науковець виокремлює 7 методів (збережено формулювання автора першоджерела), що застосовуються в Китаї щодо навчання авіаційної лексики, а саме: фонетичний метод, контекстуальноілюстративний метод, метод аналізу слова, мнемонічні допоміжні засоби, особисті словникові нотатки, орієнтовані на знання лексикографічні інструкції, перекладний метод. Підкреслюється також необхідність вивчення лексики авіації у зв'язку з авіаційною культурою й історією.

Наявні дослідження здебільшого мають констатувальний характер складності навчання студентів-авіаторів англійської лексики, а розробки детальних послідовних рекомендацій або методів навчання для забезпечення максимально ефективного опанування вокабуляром у процесі навчання в авіаційному ВНЗ є відсутніми. Питання чіткого визначення компонентів навчання майбутніх авіафахівців англомовної лексики, напрямків та стратегій такої роботи залишаються відкритими в сучасній 
методиці викладання іноземних мов.

Мета цієї статті - виокремити та обгрунтувати компоненти навчання англомовної лексики в авіаційному ВНЗ.

Наше дослідження спирається на низку вихідних теоретичних і концептуальних положень. По-перше, услід за Т. Дадлі-Еванс та Ст. Джон (1998) вважаємо, що навчання лексики при вивченні англійської мови зі спеціальною метою (ESP) (а вивчення іноземної мови в авіаційному ВНЗ є саме таким курсом, адже готує до безпосереднього використання мови для конкретних професійних завдань) спирається на загальні засади й принципи навчання англомовної лексики. По-друге, варто зазначити, що засвоєння іншомовної лексики (L2 vocabulary) може відбуватись за рахунок несвідомого опосередкованого (в англомовній літературі implicit, incidental, indirect, unplanned) вивчення (learning) або свідомого й цілеспрямованого (explicit, intentional, direct, planned) навчання (teaching, instruction). Несвідоме засвоєння лексики є побічним продуктом (by-product) при залученні студента до таких видів діяльності, як читання та слухання і не містить прямої інструкції щодо вивчення в цьому процесі нових лексичних одиниць. Свідоме ж навчання лексики стосується залучення до діяльності, що має на меті цілеспрямоване вивчення лексичних одиниць студентом [6, с. 268].

Наукові дебати про більшу значущість і першочерговість кожного із зазначених видів засвоєння лексики при опануванні іноземної мови ведуться не одне десятиріччя. Одні освітяни стверджують, що студенти можуть вивчити всю необхідну їм лексику $з$ контексту у процесі інтенсивного читання (Krashen, 1989). Інші ж, визнаючи корисність та необхідність читання, наголошують на важливості свідомого розуміння студентами завдань вивчення лексики, навчання їх свідомих стратегій вивчення слів (Ellis \& Sinclair, 1989; Hulstijn, 1997).

У ракурсі цих дебатів виокремлюємо низку тверджень, що вважаємо обгрунтованими й основоположними для нашого

(ㄱ І. Б. Файнман, Є. Б. Токарь, 2018. -264- 
дослідження. Ми наголошуємо, що:

1. Роль несвідомого засвоєння лексики за рахунок залучення в різний мовний контекст $є$ зовсім незначною на початкових етапах вивчення лексики [11, с. 16]. Це безпосередньо стосується вивчення іноземної мови для авіаційних спеціальностей, адже занурення має відбуватися у зрозуміле для студента мовне середовище (comprehensible language input), а в разі з вивченням англійської мови для потреб авіації професійний контекст $є$ абсолютно новим і незнайомим на початкових етапах навчання.

2. Засвоєння іншомовної лексики для професійного спілкування повинно мати не стихійний, а контрольований систематичний та логічний характер. Оскільки сфера професійного спілкування є чітко визначеною й потребує знання конкретних лексичних одиниць, то покладатися на їх випадковий вибір не $є$ раціональним. Окрім того, процес несвідомого засвоєння в кожного студента проходить своїм чином i не гарантує відкладання лексичних одиниць у довготривалу пам'ять.

3. Не можна повністю відкидати потенційні можливості та важливість несвідомого засвоєння лексики. Студенти вивчають / засвоюють не все, чого навчає викладач. Цілеспрямоване навчання є прямим, логічним і послідовним, а от вивчення й засвоєння у процесі такого навчання не завжди є такими [11, с. 18].

Ми визнаємо необхідність залучення студентів до несвідомого навчання лексики за рахунок читання й слухання водночас iз цілеспрямованим систематичним i послідовним навчанням лексичних одиниць зі свідомою навчальною інструкцією. «Несвідоме та цілеспрямоване вивчення лексики мають розглядатись як взаємодоповнюючі види діяльності, що обидва мають практикуватися в навчальному процесі» (курсив збережено з цитованого джерела) [6, с. 276]. Хочемо зауважити, що необхідним є не просто заохочення студентів до проведення великої кількості часу за читанням або слуханням (що хоч і може приводити до певного непослідовного випадкового вивчення 
лексичних одиниць, проте не $\epsilon$ самодостатнім), а важливо розробляти завдання, які фокусують увагу студента на вивченні лексичних одиниць і стимулюють усвідомлення важливості ефективних стратегій розширення словникового запасу.

Виходячи з теоретичних положень і концептуальних засад, обгрунтованих вище, а також аналізу науково-педагогічних i методичних джерел 3 окресленої проблематики виокремлюємо низку компонентів навчання (teaching) лексики в авіаційному навчальному закладі: 1) систематизоване свідоме навчання спеціально відібраних лексичних одиниць; 2) розширення мовного досвіду студентів; 3) навчання студентів стратегій вивчення лексичних одиниць; 4) розвиток лексичної свідомості

Систематизоване свідоме навчання спеціально відібраних лексичних одиниць. Навчання лексики відбувається за рахунок контрольованого, чітко розробленого, систематичного й упорядкованого засвоєння конкретно відібраних лексичних одиниць як загального вжитку, так і тих, значення яких охоплює коло професійної діяльності майбутніх авіаторів і $є$ актуальним для виконання їх професійних обов'язків, зокрема щодо ведення комунікативної діяльності. Хоч студенти й засвоюють значну кількість нових слів у результаті різноманітного навчального досвіду під час занять і самостійної роботи, упорядковане викладання ретельно відібраних лексичних одиниць $є$ вкрай необхідним для розуміння мовлення зі специфічним змістовим наповненням, притаманним будь-якій професійній галузі й сфері спілкування авіаторів зокрема. Як зазначають С. Датро й К. Моран, а також Л. Філмор та К. Сноу, просте занурення студентів при вивченні іноземної мови в англомовно різноманітне інтерактивне освітнє середовище $\epsilon$, на жаль, неефективним; необхідне активне, інтенсивне планування навчання академічного вокабуляру та граматики задля набуття студентами міцних i неповерхових навичок [3; 5]. Оскільки коло потенційно нових для студентів лексичних одиниць $є$ значним, а навчання є обмеженим

(ㄱ І. Б. Файнман, Є. Б. Токарь, 2018. -266- 
у часі процесом, то 3-поміж труднощів у межах діяльності викладача вирізняється визначення слів, вивчення яких буде виправданим з огляду на безпосередні систематизовані зусилля педагога. П. Нейшн (Nation) зауважує: «Викладачі повинні порізному розглядати слова, що мають високу та низьку частотність вживання. Як викладач, так і студент повинні знати, на словах якої частотності слід сфокусувати увагу. Високочастотні слова заслуговують на більшу увагу 3 боку викладача. Коли вони вивчені, викладач повинен зосередитися на навчанні студентів користуватися стратегіями вивчення й роботи над словами низької частотності» [8, с. 5]. Найбільш результативним цілеспрямоване навчання лексики виявляється тоді, коли слова, що підлягають засвоєнню, пов'язані з центральними, ключовими концептами заняття або складають лексику загального вжитку.

Визначивши слова, які потребують цілеспрямованого навчання й вивчення, викладач детально планує свою роботу, обираючи стратегії взаємодії зі студентами в цьому руслі. Різноманіття стратегій дозволяє робити заняття жвавими, динамічними, розвивати мотивацію та зацікавленість студентів, залучати їх до активної самостійної діяльності. Маємо зауважити, що цей компонент навчання студентів іншомовної лексики $€$ найбільш трудомістким і потребує значних затрат часу.

Розширення мовного досвіду студентів. Великого значення для збагачення вокабуляру студентів має також розширення мовного досвіду шляхом залучення до різноманітних видів діяльності, як-от: самостійне читання, прослуховування прочитаного кимось, усне обговорення. Традиційно більшість науковцівфілологів i методистів розглядали лексичний запас як дещо скоріше «схоплене, аніж навчене», стверджуючи, що слів просто занадто багато, щоб навчати їх обгрунтовано й ефективно у практичному плані, і що супутнє, побічне вивчення слів через різноманіття досвіду читання відповідальне за накопичення більшої частини вокабуляру. Читання, безсумнівно, дуже важливе 
для розвитку словникового запасу студентів, але, на нашу думку, випадкове вивчення нових лексичних одиниць $\epsilon$ досить довготривалим, недостатнім, малоефективним і непередбачуваним процесом, позбавленим можливості прогнозувати, які саме слова будуть вивчені, коли і на скільки глибоко та грунтовно. Ми наголошуємо, що студенти навряд чи накопичуватимуть суттєво значущі знання лексики лише через читання, позбавлене якісного й обгрунтованого керівництва цим процесом.

Роль викладача в цьому контексті полягає в розробці й застосуванні на практиці завдань, спрямованих на зростання ефективності вивчення лексики через збільшення читацького досвіду. Необхідно також додати, що різноманіття жанрів творів, які читають студенти, сприяє вивченню різнопланової лексики, а зі збільшенням обсягу читання професійно спрямованих текстів йде накопичення професійно значущої лексики, що значно додає розвиткові майбутніх авіаторів як професіоналів. Слід наголосити, що деякі дослідники підкреслюють також значущість прослуховування прочитаного й вважають, що така діяльність має потенціал для значного збагачення вокабуляру студентів [8]. На думку А. Каннінгхема та К. Становича, поєднання прослуховування 3 обговоренням прослуханого, а також мотивування до самостійного читання в позааудиторний час $\epsilon$ ефективним методом збагачення лексики [2]. Важливо, щоб викладач приділив достатньо часу таким усним видам діяльності, як обговорення почутого й прочитаного.

Навчання студентів стратегій вивчення лексичних одиниць. Наступним компонентом навчання студентів-авіаторів лексики визначаємо навчання стратегій вивчення нових слів. Студенти можуть самостійно дізнатися значення нових слів, коли вміють послуговуватися стратегіями оволодіння лексичними одиницями (аналіз структурних елементів слів (морфологічний аналіз), дослідження контексту; користування словником).

Морфологічний аналіз слова передбачає визначення його

(ㄱ І. Б. Файнман, Є. Б. Токарь, 2018. -268- 
структури. Аналіз слова за морфемами стосується встановлення значення слова шляхом дослідження його значущих елементів (морфем), таких як корінь, основа, префікси і суфікси, флективні закінчення. Дж. Бауманн та ін. зауважують: складаючи частини слова разом, студенти краще здатні усвідомити значення цілого слова [1]. Науковці стверджують, що знання морфології відіграє неоціненну роль у вивченні слів, оскільки надає студентові інформацію, корисну для дослідження незнайомих слів та усвідомлення їх значень, що суттєво розширює й поглиблює вокабуляр [4].

Аналіз контексту незнайомого слова задля з'ясування його значення передбачає активне використання тексту й ілюстрацій, що супроводжують слово [4]. Дослідження контексту відбувається на предмет таких видів підказок, як визначення, приклади, повторне вживання, яке пояснює значення вжитого слова. Читачі пристосовують швидкість читання, сповільнюючись або прискорюючись, щоб знайти необхідну інформацію.

Дж. Бауманн (2010) наголошує на важливості навчання студентів контекстного аналізу і визначає низку причин для цього:

1. Значення слова іноді наявні в реченні або реченнях, що передують або йдуть за невідомим словом.

2. У реченні або реченнях, що йдуть перед або після невідомого слова, можуть міститися підказки щодо його значення.

3. Деякі тексти подають значення слів, але студенти можуть пропустити їх.

4. Найкорисніші натяки й підказки зазвичай містяться в тому ж самому реченні, що й невідоме слово, але студенти не усвідомлюють їх.

5. Деякі підказки можуть бути оманливими. Тоді студенти мають проявити ініціативу й запитати: «Чи має це значення сенс у відповідному контексті?» [1].

Ще одним методом навчання стратегій вивчення слів $\epsilon$ використання словників. Здебільшого словник використовується, 
коли слово, прочитане в контексті, залишається незрозумілим. Навчити студентів користуватися словником - це означає навчити не лише знаходити слова за алфавітом і ключові слова у верхній частині сторінки (що зазвичай засвоюється ще на етапі навчання у школі), а правильно читати словникову статтю. Зауважимо: під час вивчення лексики в авіаційному ВНЗ варто спрямовувати студентів на те, що в разі користування загальним словником (на відміну від авіаційного), одномовним тлумачним або двомовним, значення слова, характерне для авіаційної галузі, слід шукати в кінці словникової статті, де зазвичай мають міститися й прикладі вживання слова в конкретному професійному контексті.

Розвиток лексичної свідомості. Останнім, але не менш значущим компонентом навчання лексики в авіаційному навчальному закладі ми виокремлюємо розвиток лексичної свідомості та розуміння ролі і значень слів. Лексична свідомість стосується знань і схильностей, необхідних студентові для того, щоб вчити, оцінювати й ефективно використовувати слова [9, с. 106]); це обізнаність та інтерес до слів та їх значень, різноманіття ситуацій вжитку. До такої обізнаності належить також гра слів, слова, що характеризуються тією чи тією виразністю, як-от ідіоми, образна мова.

Студенти, які усвідомлено ставляться до слів, постійно помічають їх у різних оточеннях і схоплюють їх особливі риси. Вони насолоджуються і грають словами, охоче вивчають нові. Викладач може розширювати словниковий запас студентів завдяки розвитку таких рис, як вияв значного інтересу до слів, увага до слів, вивчення нових лексичних одиниць. Стимулювання розвитку обізнаності і свідомості в межах навчання студентів лексики допомагає розвивати ці знання протягом усього життя й сприяє постійному збагаченню читацького досвіду. Студенти 3 усвідомленим ставленням та інтересом до нових слів внутрішньо мотивовані до пошуку й розкриття значень лексичних одиниць, мають високий рівень розвитку навичок вживання слів у таких

() І. Б. Файнман, Є. Б. Токарь, 2018. -270- 
видах мовленнєвої діяльності, як письмо й говоріння.

До способів розвитку обізнаності й інтересу до слів належать ігри зі словами, скоромовки, жарти, акцентування цікавих слів, що трапляються в тексті і т. ін. За такого підходу до викладання й навчання викладачі та студенти постійно звертають увагу на сферу вживання i значущість, а також змістове наповнення слів. 3 розвитком лексичної свідомості й зацікавленості новими словами студенти набувають підгрунтя для поглиблення свого словникового запасу й після закінчення професійного навчання.

Проведений аналіз дає змогу зробити висновок про необхідність поєднання опосередкованого й свідомого навчання англійської лексики в авіаційному ВНЗ. Уперше виокремлено компоненти, що охоплюють не лише пряме цілеспрямоване навчання конкретно відібраного вокабуляру, а й передбачають відносне управління несвідомим вивченням студентами лексики, навчання їх стратегій вивчення нових слів, розвиток лексичної свідомості. Результати дослідження можуть застосовуватися у практиці викладання іноземної мови в авіаційних ВНЗ задля підвищення ефективності формування лексичної компетенції майбутніх авіаторів. Перспектива ж подальших досліджень полягає в детальному обгрунтуванні прийомів i стратегій навчання, які має та може застосовувати викладач у межах кожного $з$ компонентів.

\section{Літертура}

1. Baumann J. Strategies for teaching middlegrade students to use word-part and context clues to expand reading vocabulary / Baumann J., Font G., Edwards E., Boland E. Teaching and learning vocabulary: Bringing research to practice [Ed. E. Hiebert, M. Kamil]. - New York, NY: Routledge. - 2010. - P. 179-205.

2. Cunningham A. Vocabulary growth through independent reading and reading aloud to children / A. Cunningham // Teaching and learning vocabulary: Bringing research to practice [Ed. E. Hiebert, M. Kamil]. - New York, NY: Routledge. - 2010. P. 45-65.

3. Dutro S. Rethinking English language instruction: An architectural approach / 
S. Dutro, C. Moran // English learners: Reaching the highest level of English literacy (G. Garcia, ed.). - Newark, DE: International Reading Association, 2003. - P. 227-258.

4. Edwards C. Unlocking word meanings: Strategies and guidelines for teaching morphemic and contextual analysis / Edwards C., Font G., Baumann J., Boland E. // Vocabulary instruction: Research to practice ([ds. J. Baumann and E. Kame'enui]. New York, NY : Guilford Press, 2004. - P. 159-176.

5. Fillmore L. W. What teachers need to know about language. Special report from ERIC Clearinghouse on language and linguistics // L. W. Fillmore, C. E. Snow. Electronic resource. - Mode of access: http://www.cal.org/ericcll/teachers/teachers.pdf

6. Hulstijn J. H. Intentional and incidental second-language vocabulary learning : A reappraisal of elaboration, rehearsal and automaticity / Robinson P. Cognition and Second Language Instruction. - Cambridge: Cambridge University Press, 2001. P. 258-286.

7. ICAO. Manual on the Implementaion of ICAO Language Proficiency Requirements. Doc 9835 AN 453, 2nd ed. - Montreal, Canada. - Retrieved from https://www4.icao.int/aelts/ uploads/icao\%20doc $9835 \% 202$ nd\%20edition.pdf

8. Laufer B. Ten Best Ideas for Teaching Vocabulary / B. Laufer, P. Meara, P. Nation // The Language Teacher. -2005. - 29.07, July.- P. 3-10.

9. Scott J. Developing word consciousness / J. Scott, W. Nagy // Essential readings on vocabulary instruction. (M. Graves,ed.). - Newark, DE: International Reading Association, 2009. - P. 106-117.

10. Secer Y. E. \& Sahin M. Challenges of Teaching Aviation Vocabulary and Radio Phraseology at High School Level / Y. E. Secer, M. Sahin // International Journal on New Trends in Education and Their Implications. - Vol. 5 (4). - 2014. - P. 110-120.

11. Takač V. P. Vocabulary Learning Strategies and Foreign Language Acqusition / V. P. Takač. - Clevedon : Multilingual Matters, 2008. - 196 p.

Стаття надійшла до редакиії 23.01.2018 p. 